\title{
Correction to the references Nurhasan OY et al (2006) and Tseng KH et al (2020)
}

Earth, Planets and Space*

\section{Correction to: Earth, Planets and Space (2021) 73:14 https://doi.org/10.1186/s40623-020-01349-1, Earth, Planets and Space (2021) 73:157 https://doi.org/10.1186/s40623-021-01475-4}

Following publication of the original articles (Yamada et al. 2021; Terada et al. 2021), the authors reported an error in the reference below

Nurhasan OY, Ujihara N et al (2006) Two electrical conductors beneath Kusatsu-Shirane volcano, Japan, imaged by audiomagnetotellurics, and their implications for the hydrothermal system. Earth Planets Space 58:1053-1059. https://doi.org/10.1186/BF033 52610.

The correct reference should be:

Nurhasan, Ogawa Y, Ujihara N et al (2006) Two electrical conductors beneath Kusatsu-Shirane volcano, Japan, imaged by audiomagnetotellurics, and their implications for the hydrothermal system. Earth Planets Space 58:1053-1059. https://doi.org/10.1186/ BF03352610

Following publication of the original article (Terada et al. 2021), the author reported another error in the reference below.

Tseng KH, Ogawa Y, Nurhasan TSB, Ujihara N, Honkura Y, Terada A, Usui Y, Kanda W (2020) Anat- omy of active volcanic edifice at the Kusatsu-Shirane volcano, Japan, by magnetotellurics: hydrothermal implications for volcanic unrests. Earth Planet Space 72:161. https://doi.org/10.1186/s40623-020-01283-2.

The correct reference should be:

Tseng KH, Ogawa Y, Nurhasan, Tank SB, Ujihara N, Honkura Y, Terada A, Usui Y, Kanda W (2020) Anatomy of active volcanic edifice at the Kusatsu-Shirane volcano, Japan, by magnetotellurics: hydrothermal implications for volcanic unrests. Earth Planet Space 72:161. https://doi.org/10.1186/s40623-020-01283-2.

The original articles (Yamada et al. 2021; Terada et al. 2021) have been updated.

Published online: 13 October 2021

\section{References}

Terada A, Kanda W, Ogawa Y et al (2021) The 2018 phreatic eruption at Mt. Motoshirane of Kusatsu-Shirane volcano, Japan: eruption and intrusion of hydrothermal fluid observed by a borehole tiltmeter network. Earth Planets Space. 73:157. https://doi.org/10.1186/s40623-021-01475-4 Yamada T, Kurokawa AK, Terada A et al (2021) Locating hydrothermal fluid injection of the 2018 phreatic eruption at Kusatsu-Shirane volcano with volcanic tremor amplitude. Earth Planets Space 73:14. https://doi.org/10. 1186/s40623-020-01349-1

\section{Publisher's Note}

Springer Nature remains neutral with regard to jurisdictional claims in published maps and institutional affiliations. original author(s) and the source, provide a link to the Creative Commons licence, and indicate if changes were made. The images or other third party material in this article are included in the article's Creative Commons licence, unless indicated otherwise in a credit line to the material. If material is not included in the article's Creative Commons licence and your intended use is not permitted by statutory regulation or exceeds the permitted use, you will need to obtain permission directly from the copyright holder. To view a copy of this licence, visit http://creativecommons.org/licenses/by/4.0/. 